\title{
Twelve years on: a call for papers for another special collection of articles on South Asia
}

\author{
The BMJ will revisit its ground breaking South Asia theme issue of 2004
}

\author{
Zulfiqar A Bhutta founding director ${ }^{1}$, Samiran Nundy dean ${ }^{2}$, Kamran Abbasi executive editor $^{3}$ \\ ${ }^{1}$ Center of Excellence in Women and Child Health, Aga Khan University, Karachi, Pakistan; ${ }^{2}$ Ganga Ram Postgraduate Institute for Medical Education, \\ New Delhi, India; ${ }^{3}$ The BMJ, London WC1H 9JR
}

Twelve years ago we published a special theme issue of The $B M J$ on South Asia, ${ }^{1}$ the first time that the journal had devoted a full issue to a region outside Europe. Bringing together scientists and health professionals at a time of conflict in South Asia, the theme issue covered a range of topics relevant to the region. It argued that while politics divide us, opportunities exist for people to unite across borders to tackle common health challenges.

Much has changed in 12 years. South Asia is a powerhouse of economic development, and some of the conflicts, such as those that affected Nepal and Sri Lanka, have ended. Even our definition of South Asia is different. In 2004, we focused on the seven countries in the South Asian Association for Regional Cooperation (SAARC): India, Pakistan, Bangladesh, Nepal, Sri Lanka, Bhutan, and the Maldives. Today, any consideration of South Asia must include Afghanistan, which joined SAARC in 2005, and Myanmar, which is emerging from decades of military dictatorship.

Change, however, is not always for the better. Despite gains, many of the challenges we discussed in 2004 remain. To illustrate, the overall maternal mortality ratio for South Asia fell from 288 to 176 per 100000 live births between 2005 and 2015, but maternal mortality varies 13 -fold between Sri Lanka and Afghanistan. ${ }^{2}$ Similarly, South Asia's mortality for children under 5 years dropped from a median of 75.7/1000 live births in 2005 to $51.2 / 1000$ in 2015. Again, there is a 10-fold variation between the Maldives and Pakistan and Afghanistan. ${ }^{3}$

Other challenges are more prominent. Some security issues remain, but the region is beset by emergencies such as earthquakes, floods, and droughts. The burden of non-communicable diseases is increasing. ${ }^{4}$ Widely publicised problems of gender gaps and limited opportunities for economic development and insecurity for women remain important barriers to change. ${ }^{5}$

Private sector growth has made India a hub for global medical touring, with people coming, for example, to centres of excellence in chains of private hospitals for complex cardiac and transplant surgery. ${ }^{6}$ This unrestricted corporatisation of healthcare, where the bottom line is shareholder profits, has spawned medical colleges in the private sector that offer substandard training and demand capitation fees for entry of $\$ 600000$ ( $\$ 415000 ; € 530000)$. $^{7}$ A new generation of commercially oriented doctors order unnecessary investigations and give treatments to increase a hospital's income and pay back loans for their education. ${ }^{8}$

Nonetheless, the region is advancing. Bangladesh and Nepal, not the best resourced countries in the region, achieved the millennium development goals. ${ }^{9}$ Other countries made variable but steady progress. The region is prioritising the sustainable development goals for the next 15 years.

At the same time, information technology and connectivity have spread beyond the elite and privileged to affect the lives of the masses. Seven hundred million Indians (out of a population of 1.2 billion) now possess mobile phones. ${ }^{10}$ Growth of electronic and social media in the region is exponential, providing an essential communications tool for politicians, civil society, and health professionals.

However, the proportion of national budgets allocated to healthcare remains too low, ranging from $1 \%$ to $3 \%$ of gross domestic product. ${ }^{11}$ Hence, despite numerous efforts at organising rural and primary care and promoting health insurance, huge disparities remain in healthcare delivery and access to essential services. These are major challenges for the future, especially as universal and equitable healthcare is a cornerstone for achieving the sustainable development goals related to health.

The BMJ has retained and expanded its interest in South Asia. Editors are now based in the region. Our website (thebmj.com) offers a dedicated channel for readers in South Asia, where all content relevant to the region is freely available. ${ }^{12} T h e B M J$ 's campaign against corruption in medicine caught the public's imagination in India, gaining support among doctors and contributing to major social, political, and legal initiatives to improve professional standards and behaviour. ${ }^{13}$ 
The BMJ is planning another special collection of articles on South Asia with the aim of revisiting existing challenges and addressing those that have emerged since our previous theme issue. Again, we will work with experts from across the region to guide us and contribute. You can leave a rapid response to this editorial on thebmj.com to suggest what we might cover. In addition, we particularly welcome submission of original research and analysis articles for inclusion in the collection. We also welcome editorials and other opinion pieces. All submissions will be subject to the journal's usual editorial and peer review processes.

Although South Asia is emerging as a dynamic region offering great opportunity, it is hampered by some of the world's worst development indicators. It remains divided by politics and religion, and the baggage of a painful partition. Yet our belief is that South Asia can progress most rapidly through cooperation and mutual respect, by investing in science and knowledge, and by improving the lives of its poor and disenfranchised. A focus on health can unite, inspire, and transform, and may well lay the ground work for lasting peace. We hope The BMJ's special collection on South Asia will show the way.

Competing interests: We have read and understood BMJ policy on declaration of interests and have no relevant interests to declare.
Provenance and peer review: Commissioned; not externally peer reviewed.

South Asia theme issue. BMJ 2004:328(7443). http://www.bmi.com/content/328/7443

2 WHO, Unicef, UNFPA, World Bank Group, United Nations Population Division. Trends in maternal mortality, 1990 to 2015. http://apps.who.int/iris/bitstream/10665/194254/1/ 9789241565141_eng.pdf?ua=1

3 UN Inter-agency Group for Child Mortality Estimation. Child mortality estimates. Global and regional under-five and infant mortality rates and deaths, by MDG regions. 2015. http://www.childmortality.org

4 Siegel KR, Patel SA, Ali MK. Non-communicable diseases in South Asia: contemporary perspectives. Br Med Bull 2014;111:31-44. doi:10.1093/bmb/ldu018 pmid:25190759.

5 Ferdousy EZ, Matin MA. Association between intimate partner violence and child morbidity in South Asia. J Health Popul Nutr 2015;33:16. doi:10.1186/s41043-015-0016-y. pmid: 26825360.

6 Sengupta A, Nundy S. The private health sector in India. Burgeoning at the cost of public health care. BMJ 2005;331:157-8doi:10.1136/bmj.331.7526.1157.

7 Seethalakshmi S, PG medical seats auctioned for Rs 4 crores. TNN 2013 Sep 13.

8 Gadre A, Shukla A, eds. Health care becomes an industry. The growing influence of corporate and multispecialty hospitals. In: Dissenting diagnosis. Random House, 2016:44-59.

9 Countdown to 2015. Final report 2015. http://www.countdown2015mnch.org/reports-andarticles/2015-final-report

10 Smartphone market share http://www.idc.com/prodserv/smartphone-market-share.jsp

11 World Bank. Health expenditure as a \% of gross domestic production (GDP). 2016. http //data.worldbank.org/indicator/SH.XPD.TOTL.ZS

12 Prashant J. The BMJ's free access trial for South Asian content. http://blogs.bmj.com/ bmi/2016/03/09/prashant-jha-the-bmis-free-access-trial-to-south-asian-content/

13 Jain A, Nundy S, Abbasi K. Corruption: medicine's dirty open secret. BMJ 2014;348:g4184.pmid:24965786.

Published by the BMJ Publishing Group Limited. For permission to use (where not already granted under a licence) please go to http://group.bmj.com/group/rights-licensing/ permissions 